\title{
PENERAPAN MODEL QUANTUM TEACHING UNTUK MENINGKATKAN HASIL BELAJAR IPA SISWA KELAS IIIB SD NEGERI 188 PEKANBARU
}

\author{
Sihol Martua Panjaitan*, Mahmud Alpusari, Lazim N \\ Pendidikan Guru Sekolah Dasar Fakultas Keguruan dan IImu Pendidikan, \\ Universitas Riau, Pekanbaru, Indonesia \\ *siholmartuapanjaitan0@gmail.com
}

\begin{abstract}
This research is motivated by the low value of Natural sciense in grade IIIB students at SDN 188 Pekanbaru, this is caused by several factors, namely 1) The lack of teachers involves students in active learning, 2) Teachers rarely do varying learning methods so they use the lecture method more 3) More theory than the practice given by the teacher, 4) The teacher does not understand the personal characteristics of each student. For this reason, researchers try to apply an interactive learning model and create a fun and enjoyable learning environment for students, namely the Quantum teaching model. Which aims to improve the learning outcomes of class IIIB students at SDN 188 Pekanbaru. This research is a classroom action research, carried out in 3 cycles with 2 meetings and 1 daily replication in each cycle, it aims to see the development of learning outcomes each cycle. Based on data from classroom action research, by applying the Quantum teaching model conducted from April 16 to May 10, 2018, it can be seen that there is an increase in the average student learning outcomes in each cycle, starting from the initial data collection of the average score of the basic score 67.5 in the implementation of cycle 1 the average student learning outcomes increased to 72.59 , then in cycle 2 it increased to 76.28 , then in cycle 3 it increased again to 80.36. This it can be concluded that the application of the Quantum teaching model can improve the Natural sciense learning outcomes of grade IIIB students at SDN 188 pekanbaru
\end{abstract}

Keywords: Model Quantum teaching, The results of Natural sciense

\section{PENDAHULUAN}

Pendidikan bagi suatu bangsa merupakan suatu kebutuhan dasar yang harus dipenuhi untuk meningkatkan kualitas sumber daya manusia. Dalam undang-undang nomor 20 tahun 2003 tentang sistem pendidikan nasional menyatakan bahwa pendidikan nasional berfungsi untuk mengembangkan

S. M. Panjaitan, M. Alpusari, \& Lazim. N, Penerapan model quantum teaching Untuk meningkatkan Hasil Belajar IPA Siswa Kelas IIIB SD Negeri 188 Pekanbaru 
kemampuan dan membentuk watak serta peradaban bangsa yang bermartabat dalam rangka mencerdaskan kehidupan bangsa.

Pendidikan adalah usaha sadar dan terencana untuk mewujudkan suasana belajar dan proses pembelajaran agar peserta didik secara bergerak aktif mengembangkan potensi dirinya untuk memiliki kekuatan spiritual keagamaan, pengendalian diri, kepribadian, kecerdasan, akhlak mulia serta keterampilan yang diperlukan dirinya, masyarakat dan negara. Pendidikan terbagi menjadi dua jenis yaitu pendidikan formal dan nonformal. pendidikan yang pada umumnya di jalani orang-orang adalah pendidikan formal seperti bersekolah. Disekolah kita dapat memperoleh banyak ilmu pengetahuan salah satunya adalah IPA.

IPA adalah IImu pengetahuan yang membahas hubungan Manusia, Binatang, dengan lingkungannya. Menurut KTSP (2007) Pembelajaran IPA SD adalah pembelajaran menekankan pada pemberian pengalaman langsung untuk mengembangkan kompetensi agar menjelajahi dan memahami alam sekitar secara ilmiah. Pembelajaran IPA diarahkan untuk inkuiri dan berbuat sehingga dapat membantu peserta didik untuk memperoleh pemahaman yang lebih mendalam tentang alam sekitar. menanamkan Pada peserta didik untuk berpikir kritis dan menumbuhkan rasa ingin tahu.

Berdasarkan hasil observasi dan dokumentasi dengan Ibu Umi silawati selaku wali kelas IIIB, diperoleh data masih rendahnya hasil belajar IImu pengetahuan alam kelas IIIB untuk lebih jelasnya dapat dilihat pada data berikut ini: 1) Jumlah siswa 32 orang, KKM yang ditetapkan sekolah pada mata pelajaran IImu Pengetahuan Alam adalah 72, 2) Jumlah siswa yang mencapai KKM berjumlah 13 orang $(41 \%)$, 3) Jumlah siswa yang belum mencapai KKM berjumlah 19 orang $(59 \%)$, 4) Nilai rata-rata siswa secara keseluruhan 67,5. Rendahnya hasil belajar siswa kelas IIIB SD Negeri 188 Pekanbaru pada mata Pelajaran IPA di sebabkan oleh beberapa faktor antara lain: 1) Kurangnya Guru melibatkan siswa pada pembelajaran yang aktif, 2) Guru jarang melakukan metode-metode pembelajaran yang bervariasi sehingga lebih banyak menggunakan metode ceramah 3) Lebih banyak teori dari pada praktek yang diberikan oleh guru, 4) Guru kurang memahami karakteristik pribadi masing-masing siswa. Gejalanya 
adalah: 1) Siswa kurang mampu melaksanakan tugas yang diberikan oleh guru, 2) Siswa kurang mengikuti pembelajaran dengan baik, 3) Siswa kurang begitu mengetahui cara menggunakan media-media pembelajaran dalam praktek pelajaran IImu Pengetahuan Alam, 4) Siswa cenderung diam ketika diberi pertanyaan oleh guru.

Dari hasil dokumentasi dengan guru kelas IIIB SD Negeri 188 Pekanbaru menyatakan bahwa guru tersebut telah melakukan upaya untuk memperbaiki hasil belajar IPA yaitu dengan melakukan remedial kepada siswanya. Namun upaya tersebut belum bisa dikatakan berhasil karena hasil belajar siswa masih banyak yang rendah.

Berdasarkan dari permasalahan yang ada sebaiknya guru harus mampu menciptakan suasana belajar yang bervariasi atau menyenangkan dengan memilih model atau metode pembelajaran yang berpusat pada anak. Karena jika pembelajaran berpusat pada anak maka anak akan lebih aktif dalam pembelajaran. Anak akan sering mengemukakan pendapatnya. Guru haruslah memahami karakter pribadi masing-masing peserta didiknya sehingga guru mampu menyikapi peserta didiknya dengan pola pengajarannya. Dan lebih baik lagi jika guru berhasil menciptakan daya saing secara sehat di kelas dengan memberikan reward kepada anak yang lebih unggul dan memberikan motivasi yang mendalam kepada anak yang lemah dalam menerima pelajaran, dengan begitu anak akan memperhatikan penjelasan guru secara baik dan banyak mencari pengetahuan tambahan agar anak mampu menyelesaikan masalah selama pembelajaran. Jika anak menikmati pelajaran yang diajarkan oleh guru maka hasil belajar anak pasti akan meningkat juga

Berdasarkan uraian latar belakang masalah yang dipaparkan, peneliti melakukan penelitian dengan judul "Penerapan Model Quantum Teaching Untuk Meningkatkan Hasil Belajar IPA Siswa Kelas IIIB SD Negeri 188 Pekanbaru. rumusan masalah dalam penelitian ini adalah "Apakah penerapan model Quantum Teaching dapat meningkatkan hasil belajar IPA siswa kelas III SD Negeri 188 Pekanbaru? ", penelitian ini bertujuan untuk meningkatkan hasil belajar IPA siswa kelas III SD Negeri 188 Pekanbaru dengan penerapan model Quantum Teaching. 
Kemudian Penelitian ini juga dapat memberikan manfaat kepada beberapa pihak yaitu: 1) bagi siswa hasil belajar siswa akan meningkat dengan penerapan model Quantum Teaching, 2) bagi guru, guru memperoleh informasi tentang model pembelajaran yang dapat membuat siswa aktif yaitu model quantum teaching, 3) bagi sekolah dengan adanya model pembelajaran yang baik maka sekolah mampu menciptakan siswa yang cerdas dan berprestasi, 4) bagi peneliti lain hasil penelitian ini diharapkan menjadi referensi atau sumber tambahan bagi peneliti lain dalam rangka menindak lanjuti penelitian dengan ruang lingkup yang lebih luas.

\section{METODE PENELITIAN}

Penelitian ini dilaksanakan di SD Negeri 188 Pekanbaru, pada semester ganjil 2017/2018. Subjek dalam penelitian ini adalah siswa kelas IIIB SDN 188 Pekanbaru, dengan jumlah murid 33 orang siswa. Yang terdiri dari 22 orang siswa laki-laki dan 11 orang siswa perempuan. Desain penelitian ini adalah penelitian tindakan kelas (PTK). Penelitian tindakan kelas adalah penelitian praktis yang bertujuan untuk memperbaiki kekurangan-kekurangan dalam pembelajaran dikelas.

Penelitian tindakan kelas (PTK) dalam penelitian ini dilaksanakan dalam beberapa tahapan yaitu tahap perencanaan, tahap pelaksanaan, tahap pengamatan, dan tahap refleksi, Penelitian tindakan kelas dalam penelitian ini dilaksanakan sebanyak tiga siklus, pada setiap siklusnya dilakukan dengan penerapan model quantum teaching.

Kemudian instrumen penelitian ini adalah berupa rencana pelaksanaan pembelajaran (RPP), lembar kerja siswa (LKS), dan lembar evaluasi. Sedangkan instrumen pengumpulan data dalam penelitian ini adalah tekhnik observasi dan tekhnik tes. Data yang telah diperoleh dari lembar pengamatan dan tes hasil belajar ilmu pengetahuan alam akan dianalisis dengan menggunakan teknik analisis desrkriptif, yaitu dengan cara memberi gambaran atau memaparkan semua aktivitas yang dilakukan siswa dan guru selama proses pembelajaran serta ketuntasan belajar siswa.

S. M. Panjaitan, M. Alpusari, \& Lazim. N, Penerapan model quantum teaching Untuk meningkatkan Hasil Belajar IPA Siswa Kelas IIIB SD Negeri 188 Pekanbaru 
Teknik analisis data aktivitas guru dan siswa selama kegiatan belajar mengajar dibukukan pada observasi dengan rumus:

$\mathrm{NR}=\frac{J S}{S M} X 100 \% \quad \mathrm{KTSP}$ (Syahrilfuddin, 2011)

Keterangan:

$\mathrm{NR}=$ Ketercapaian indikator

JS = Skor yang diperoleh siswa

$\mathrm{SM}=$ Skor maksimum

Tabel 1

Kategori Persentase Aktivitas Guru dan Siswa

\begin{tabular}{|l|l|l|}
\hline Nilai & Interval \% & Kategori \\
\hline 4 & $81-100$ & Sangat baik \\
\hline 3 & $61-80$ & Baik \\
\hline 2 & $51-60$ & Cukup \\
\hline 1 & Kurang dari 50 & Kurang \\
\hline
\end{tabular}

Sumber: KTSP (2004)

Analisis data hasil belajar IPA siswa pengelolaan data ini dilakukan dengan analisia deskriptif untuk mendeskripsikan hasil belajar siswa setelah menerapkan model quantum teaching. Skor hasil belajar diperoleh dan dianalisis berdasarkan:

Ketuntasan Individu dalam penelitian ini, siswa dikatakan tuntas belajar apabila mendapat nilai 70 berdasarkan KKM yang ditetapkan sekolah. Ketuntasan belajar siswa dihitung dengan menggunakan rumus:

$$
\mathrm{HB}=\frac{\text { jumlah jawaban benar }}{\text { jumlah soal }} X 100
$$

Zetra Hainul (2015)

Ketuntasan klasikal Ketuntasan belajar secara klasikal menurut Mulyasa (2009) adalah suatu ketuntasan belajar yang apabila 75\% dari siswa tuntas belajar. Untuk menghitung ketuntasan klasikal digunakan rumus:

$$
\mathrm{PK}=\frac{S T}{N} X 100 \%
$$

Purwanto (Syahrilfuddin, 2011)

Keterangan:

PK $=$ Persentase ketuntasan klasikal

S. M. Panjaitan, M. Alpusari, \& Lazim. N, Penerapan model quantum teaching Untuk meningkatkan Hasil Belajar IPA Siswa Kelas IIIB SD Negeri 188 Pekanbaru 
$\mathrm{N}=$ Jumlah siswa yang tuntas

ST = Jumlah siswa seluruhnya

Rata-rata hasil belajar untuk menghitung rata-rata hasil belajar bahasa indonesia adalah dengan cara menjumlahkan semua nilai data dibagi banyaknya data dengan menggunakan rumus:

$$
X=\frac{\sum x 1}{N}
$$

Keterangan:

$X=$ mean/rata-rata

$\sum X_{1}=$ jumlah tiap data

$\mathrm{N}=$ jumlah data

Peningkatan hasil belajar untuk mengetahui persentase peningkatan hasil belajar siswa diperoleh dengan menggunakan rumus:

$\mathrm{P}=\frac{\text { Posrate-Baserate }}{\text { Baserate }} X 100 \%$

Keterangan:

$\mathrm{P}=$ persentase peningkatan

Posrate $=$ nilai rata-rata sesudah tindakan

Baserate $=$ nilai rata-rata sebelum tindakan

\section{HASIL}

\section{Penilaian Aktivitas Guru}

Penilaian aktivitas guru pada setiap siklusnya terjadi peningkatan, hal-hal yang kurang maksimal yang dilakukan guru dalam pengajaran pada awal-awal pertemuan mulai diperbaiki guru pada pertemuan berikutnya, hal ini dapat dilihat dari data yang telah didapatkan pada pertemuan pertama dalam siklus satu skor yang didapati guru hanya 14 dengan persentase 58,33\% yang dikategorikan cukup, lalu pada pertemuan kedua siklus satu terjadi peningkatan jumlah skor yang didapati guru berjumlah 17 dengan persentase $70,83 \%$ dan kategori baik, begitu pula pada siklus kedua pertemuan pertama guru mendapatkan jumlah skor 19 dengan persentase $82,60 \%$ yang dikategorikan sangat baik, lalu pada pertemuan kedua siklus kedua terjadi lagi peningkatan skor yang diperoleh guru 
sebanyak 21 dengan peresentase 87,5\% yang dikategorikan sangat baik, kemudian pada siklus ketiga pertemuan pertama guru kembali mendapatkan skor berjumlah 22 dengan persentase $91,66 \%$ yang dikategorikan sangat baik lalu pada pertemuan kedua guru mendapattkan skor 23 yang dipersentasekan sejumlah 95,83\% dengan kategori sangat baik, hal ini dapat disimpulkan bahwa setiap siklusnya guru selalu memperhatikan cara ajar guru setiap pertemuan dalam siklusnya mengevaluasi cara ajar guru dalam tiap pertemuannya sehingga pada penilaian aktivitas guru skor, jumlah persentase, dan kategori yang didapat guru meningkat.

\section{Penilaian Aktivitas Siswa}

Penilaian aktivitas siswa pada penelitian ini data yang didapati dari penilaian observer pada setiap siklusnya aktivitas siswa didalam kelas dalam tiaptiap pertemuan meningkat, hal ini dapat dilihat dari data yang telah didapatkan pada siklus satu pertemuan pertama siswa mendapatkan skor berjumlah 13 dan pertemuan kedua skor yang diperoleh siswa meningkat berjumlah 15 , begitu pula dengan persentase dan kategori yang didapatkan siswa, pada pertemuan pertama siswa mendapatkan persentase $54,16 \%$ dengan kategori cukup, lalu pada pertemuan kedua siswa mendapatkan persentase $62,5 \%$, lalu pada siklus kedua terjadi kembali peningkatan aktivitas siswa dalam setiap pertemuannya dengan skor yang didapati dalam aktivitas siswa pada pertemuan pertama berjumlah 16 dengan persentase $66,66 \%$ kategori baik, dalam pertemuan keduan skoryang didapatkan berjumlah 17 dengan persentase $70,83 \%$ dengan kategori baik, lalu pada siklus ketiga juga telah terjadi peningkatan dalam setiap siklusnya dalam pertemuan pertama skor yang didapati berjumlah 20 dengan persentase 83,33\% kategori sangat baik, lalu pada pertemuan kedua skor aktivitas siswa meningkat menjadi 22 dengan persentase $91,66 \%$ dengan kategori sangat baik, hal ini dapat disimpulkan dalam setiap siklusnya aktivitas siswa dalam mengikuti pengajaran yang diberikan guru telah terjadi peningkatan siswa mulai terbiasa dengan metode pembelajaran yang diajarkan guru sehingga aktivitas siswa dalam tiap siklusnya meningkat

\section{Peningkatan Hasil Belajar}

S. M. Panjaitan, M. Alpusari, \& Lazim. N, Penerapan model quantum teaching Untuk meningkatkan Hasil Belajar IPA Siswa Kelas IIIB SD Negeri 188 Pekanbaru 
Hasil belajar siswa dalam setiap siklusnya meningkat dengan data yang telah diolah oleh guru pada skor dasar rata-rata hasil belajar siswa hanya 67,5. Kemudian meningkat pada siklus pertama rata-rata hasil belajar siswa meningkat menjadi 72,32 dengan persentase skor ulangan harian siklus satu berjumlah 7,14, lalu pada siklus kedua rata-rata hasil belajar siswa juga meningkat berjumlah 76,28 dengan persentase skor ulangan harian berjumlah 13\%, dan pada siklus ketiga rata-rata hasil belajar siswa juga meningkat menjadi 80,36 dengan persentase skor ulangan harian sejumlah $13 \%$, artinya melalui penerapan model quantum teaching hasil belajar siswa meningkat dalam setiap ulangan harian siklusnya karena pembelajaran yang dilakukan tidak lagi menekankan keaktifan guru didalamnya melainkan keaktifan siswa

\section{Ketuntasan Belajar Siswa}

Ketuntasan hasil belajar siswa sebelum dan sesudah tindakan juga terjadi peningkatan dapat diperoleh data yang telah diolah oleh guru jumlah siswa pada skor dasar sejumlah 32 orang, siswa yang tuntas hanya 13 orang dengan persentase $40,62 \%$ dengan ketuntasan klasikal yidak tuntas, pada siklus satu jumlah siswa 33 orang siswa yang tuntas meningkat menjadi 19 orang dengan persentase $57,57 \%$ dengan ketuntasan klasikal tidak tuntas, lalu pada siklus kedua jumlah siswa 33 orang ketuntasan hasil belajar siswa yang tuntas meningkat menjadi 24 orang dengan persentase $72,72 \%$ dengan ketuntasan klasikal tidak tuntas, kemudian pada siklus ketiiga jumlah siswa 33 orang ketuntasan hasil belajar siswa yang tuntas berjumlah 29 orang dengan persentase $87,87 \%$ dengan ketuntasan tuntas hal ini disebabkan apabila ketuntasan belajar siswa mencapai

$75 \%$ ketuntasan klasikal adalah tuntas

Berdasarkan hasil dari data yang telah didapat, dapat diambil kesimpulan bahwa penerapan model quantum teaching dapat meningkatkan hasil belajar IPA siswa kelas IIIB SDN 188 PEKANBARU dengan persentase ketuntasan hasil belajar siswa sebelum dan sesudah tindakan pada siklus III adalah $87,87 \%$.

\section{PEMBAHASAN}

S. M. Panjaitan, M. Alpusari, \& Lazim. N, Penerapan model quantum teaching Untuk meningkatkan Hasil Belajar IPA Siswa Kelas IIIB SD Negeri 188 Pekanbaru 
Berdasarkan analisis hasil penelitian yang telah dilaksanakan, diketahui bahwa setelah diberi tindakan siklus I, II dan siklus III terjadi peningkatan dalam proses belajar maupun hasil belajar IPA siswa. Hasil belajar IPA siswa kelas IIIB sebelum diterapkan model Quantum teaching tergolong rendah. Berdasarkan data awal yang diperoleh dari hasil observasi diketahui bahwa hasil belajar pada mata pelajaran IPA masih rendah dari KKM yang telah ditetapkan yaitu 72 , siswa yang mencapai KKM 13 orang (41\%) sedangkan jumlah siswa yang belum mencapai KKM sebanyak 19 orang (59\%) dengan nilai rata-rata kelas 67,5. Dari data-data tersebut ditemukan gajala-gejala yang muncul pada sikap siswa dalam proses pembelajaran yaitu pasif pada pembelajaran dan siswa tidak termotivasi dalam mengikuti kegiatan pembelajaran. Gejala yang timbul tersebut disebabkan oleh guru yang lebih sering menggunakan metode ceramah dan mengedepankan Teacher center sehingga proses komunikasi pembelajaran yang terjadi hanya satu arah, guru jarang menggunakan pembelajaran berkelompok dan guru tidak menggunakan media dalam proses pembelajaran.

Berdasarkan analisis hasil tindakan diperoleh data bahwa aktivitas guru mengalami peningkatan pada setiap siklus dengan menerapkan model Quantum teaching. Pada siklus I pertemuan pertama aktivitas guru masih terdapat kekurangan seperti halnya guru masih kurang dalam menyampaikan materi pelajaran, guru kurang bisa menguasai kelas dengan baik pada saat pembelajaran dan pembagian kelompok, sehingga aktivitas guru dikategorikan cukup dengan persentase 58,33\%. Pada siklus I pertemuan kedua aktivitas guru mengalami peningkatan, guru sudah mulai terlihat percaya diri dalam menyampaikan materi dan guru sudah mulai bisa mengontrol siswa walaupun masih terdapat banyaknya siswa yang susah diatur namun tidak sebanyak dipertemuan pertama, sehingga dikategorikan baik dengan persentase $70,83 \%$. Selanjutnya pada siklus II pertemuan pertama aktivitas guru juga mengalami peningkatan, dimana pendekatan guru dan siswa sudah tampak baik sehingga guru dalam menyampaikan materi sudah baik dan mampu menguasai kelas dengan baik, sehingga dikategorikan sangat baik dengan persentase $82,60 \%$. Pada siklus II pertemuan kedua aktivitas guru dikategorikan sangat baik karena 
pembelajaran yang dilakukan sudah berjalan dengan lancar dan lebih baik dibandingkan dengan pertemuan-pertemuan sebelumnya dan memposisikan guru sendiri sebagai fasilitator sehingga dikategorikan sangat baik dengan persentase $87,5 \%$. Pada siklus III pertemuan pertama aktivitas guru sudah sangat memuaskan, guru sudah berhasil memposisikan dirinya sebagai fasilitator siswa dikelas dalam melaksanakan kegiatan yang dilakukan guru tidak tampak suatu hambatan yang berarti, dan menjadikan suasana kelas menjadi menyenangkan menumbuhkan rasa semangat siswa dalam belajar sehingga dikategorikan sangat baik dengan persentase $91,66 \%$. pada siklus III pertemuan kedua aktivitas guru sudah sangat meningkat dengan pembelajaran yang menarik yang diterapkan guru melalui model Quantum teaching, guru sudah terbiasa menguasai kelas dengan baik dan santai sehingga dikategorikan sangat baik dengan persentase 95,83\%, Menurut Dimyati (2013) hasil belajar adalah berkat tindak guru dalam pencapaian tujuan pembelajaran sebagai dampak pengajaran dan dampak pengiring. Peningkatan aktivitas guru ini membuktikan bahwa guru sudah bisa mengarahkan siswa kepada tujuan pembelajaran. Hal ini sesuai dengan yang diungkapkan oleh Trianto (2007) dalam mengajarkan suatu materi, Guru harus memilih model pembelajaran yang paling sesuai dengan tujuan pembelajaran. Menurut Sutrisno (2005) bahwa Quantum Teaching berisi prinsip-prinsip sistem perancangan pengajaran yang efektif, efisien dan progresif berikut metode penyajiannya untuk mendapatkan hasil belajar yang mengagumkan dengan waktu sedikit, Deporter (2000) menyatakan bahwa, Quantum Teaching menunjukan kepada anda menjadi guru yang baik. Quantum Teaching cara-cara yang baru yang memudahkan proses belajar lewat pemanduan unsur seni dan pencapaianpencapaian yang terarah, apapun mata pelajaran yang anda ajarkan. Maka dari itu dalam proses pembelajaran yang dilakukan dalam aktivitas guru melalui model Quantum teaching telah terlaksana dengan baik.

Aktivitas siswa pada setiap pertemuan siklus I, II dan III juga mengalami peningkatan. Pada siklus I pertemuan pertama aktivitas siswa dikategorikan cukup karena masih terdapat beberapa kekurangan yaitu siswa kurang aktif, siswa masih banyak yang bermain-main dan ribut serta dalam diskusi masih banyak siswa 
yang belum aktif dan sibuk melakukan kegiatannya sendiri sehingga diperoleh persentase sebesar $54,16 \%$. Pada siklus I pertemuan kedua aktivitas siswa dikategorikan baik, pada saat proses pembelajaran berlangsung terdapat beberapa siswa yang masih ada tidak serius mendengarkan penjelasan guru dan dalam keadaan ribut pada saat pembelajaran berlangsung lalu siswa masih belum terlihat aktif dalam kelompok dan berdiskusi tampak masih adanya keragu-raguan maupun rasa enggan dan malu sehingga aktivitas siswa pada pertemuan kedua siklus I diperoleh persentase sebesar $62,5 \%$. Pada siklus II pertemuan pertama aktivitas siswa dikategorikan baik dengan persentase $66,66 \%$, karena siswa sebagian sudah mulai fokus dan mendengarkan guru menyampaikan materi, kemudian tingkat kebisingan dikelas mulai berangsur-angsur berkurang walau masih terdapat gangguan dalam proses belajar misalnya berbicara dengan teman sebangk dan menggangu teman yang lainnya dalam belajar. Siklus II pertemuan kedua aktivitas siswa dikategorikan baik, pada pertemuan ini sudah berjalan lancar dibandingkan pertemuan sebelumnya, siswa sudah bisa menempatkan diri didalam kelompoknya dan bekerja sama dengan baik sehingga persentase aktivitas siswa meningkat menjadi 70,83\%. Pada siklus III pertemuan pertama, siswa sudah terlihat antusias dan aktif dalam proses pembelajaran, dan juga sudah terbiasa dengan model Quantum teaching, sehingga aktivitas siswa dikategorikan sangat baik dengan persentase $83,33 \%$, Pada siklus III pertemuan yang kedua dengan kategori sangat baik, siswa sudah nyaman dalam pembelajaran dikelas dan belajar dengan menyenangkan sehingga persentase aktivitas siswa meningkat menjadi $91,66 \%$ hal ini selaras dengan pendapat Anitah (2009) model pembelajaran Quantum Teaching yaitu suatu model pembelajaran yang meciptakan pembelajaran yang bergairah dan menyenangkan. Adanya peningkatan aktivitas siswa pada setiap siklus dikarenakan siswa dalam mengikuti proses belajar semakin fokus dan baik serta meningkatnya kerjasama siswa dalam mengerjakan tugas kelompoknya. Sehingga proses pembelajaran telah sesuai dengan yang diharapkan dan menunjukkan adanya peningkatan kualitas aktivitas siswa. Hal ini sesuai dengan yang diungkapkan Deporter (1992) bahwa quatum teaching adalah model yang membuat susasana kelas menjadi 
menyenangkan, membuat siswa aktif dan tidak mudah bosan dalam proses pembelajaran Karena setiap langkah-langkah dalam quantum teaching selalu melibatkan siswa.

Berdasarkan analisis hasil belajar siswa dari skor dasar hingga siklus III diperoleh data bahwa hasil belajar dan peningkatan hasil belajar IPA telah terjadi peningkatan setelah diterapkan model Quantum teaching ini serta ketuntasan belajar baik individu maupun klasikal juga mengalami peningkatan pada setiap siklusnya. Hal ini berdasarkan ulangan harian yang telah dilaksanakan oleh siswa. Pada setiap siklusnya juga terjadi peningkatan siswa yang tuntas, hingga pada ulangan harian 3 siswa yang tidak tuntas hanya 4 orang. Dan peningkatan hasil belajar siswa dengan rata-rata dari skor dasar yang berjumlah 67,5 meningkat pada UH siklus I menjadi 72,59 dengan persentase $7,54 \%$, lalu meningkat pula dalam UH siklus II menjadi 76,28 dengan persentase 13\%, kemudian meningkat dalam UH siklus III menjadi 80,36 dengan persentase 19,05\%. Berdasarkan pengamatan peneliti bahwa setelah diterapkan model Quantum teaching, siswa tertarik dan termotivasi untuk mengikuti pembelajaran karena sangat menarik yang membuat siswa tertarik mengikuti pembelajaran yang diberikan oleh guru dengan meningkatnya hasil belajar siswa sangatlah berkaitan dengan apa yang dikemukakan oleh Abdurrahman (Asep Jihad, 2012) hasil belajar adalah kemampuan yang diperoleh anak setelah melalui kegiatan belajar. Jadi dapat disimpulkan bahwa hasil belajar IPA adalah tingkat keberhasilan siswa dalam mata pelajaran IPA yang diperoleh dari hasil tes dalam bentuk angka-angka atau skor setelah siswa selesai melakukan proses pembelajaran IPA.

\section{SIMPULAN DAN SARAN}

\section{simpulan}

Berdasarkan data hasil penelitian tindakan kelas dengan penerapan model Quantum teaching dapat diambil kesimpulan, bahwa penerapan model Quantum teaching dapat meningkatkan hasil belajar bahasa indonesia siswa kelas IIIB SD Negeri 188 Pekanbaru. Besar peningkatan dapat dilihat dari:

Aktivitas guru dan siswa mengalami peningkatan. Dalam pelaksanakan pembelajaran siklus I pada pertemuan pertama aktivitas guru dengan persentase 
$58,33 \%$ dengan kategori cukup, selanjutnya pada pertemuan kedua mengalami peningkatan sebesar $70,83 \%$ dengan kategori baik. Kemudian pada siklus II pertemuan pertama meningkat lagi sebesar $82,60 \%$ kategori sangat baik dan pertemuan kedua meningkat menjadi $87,5 \%$ dengan kategori sangat baik. Kemudian pada siklus III pertemuan pertama meningkat lagi sebesar 91,66\% dengan kategori sangat baik dan pada pertemuan kedua meningkat menjadi 95,83\% dengan kategori sangat baik. Kemudian, persentase aktivitas siswa juga mengalami peningkatan. Pada siklus I pertemuan pertama aktivitas siswa sebesar $54,16 \%$ dengan kategori cukup, dan pada pertemuan kedua meningkat menjadi $62,5 \%$ dengan kategori baik. Kemudian pada siklus II pertemuan pertama aktivitas siswa sebesar $66,66 \%$ kategori baik dan pada pertemuan kedua meningkat lagi sebesar $70,83 \%$ dengan kategori baik. Kemudian pada siklus III pertemuan pertama aktivitas siswa sebesar $83,33 \%$ dengan kategori sangat baik dan pada pertemuan kedua meningkat kembali menjadi $91,66 \%$ dengan kategori sangat baik.

Hasil belajar siswa mengalami peningkatan. Rata-rata hasil belajar pada data awal sebelum tindakan yaitu senilai 67,65 meningkat pada siklus I menjadi 72,32 dengan persentase peningkatan sebesar $7,14 \%$ meningkat lagi pada siklus II menjadi 76,28 dengan persentase peningkatan sebesar 13\% kemudian meningkat kembali pada siklus III menjadi 80,36 dengan presentase peningkatan sebesar $19,05 \%$. Meningkatnya hasil belajar juga mempengaruhi ketuntasan hasil belajar individu dan klasikal. Pada siklus I diketahui 19 (57,57\%) siswa yang tuntas dan $14(42,42 \%)$ siswa yang tidak tuntas. Selanjutnya pada siklus II siswa yang tuntas berjumlah 24 (72,72\%) siswa dan siswa yang tidak tuntas $9(27,27 \%)$ siswa. Kemudian pada siklus III siswa yang tuntas berjumlah $29(87,87 \%)$ siswa dan siswa yang tidak tuntas $4(12,12 \%)$ siswa.

\section{Saran}

Model Quantum teaching dapat dijadikan salah satu inovasi dalam proses pembelajaran yang dapat diterapkan oleh guru, karena melalui model ini dapat meningkatkan aktivitas guru dan aktivitas siswa dalam proses pembelajaran.

S. M. Panjaitan, M. Alpusari, \& Lazim. N, Penerapan model quantum teaching Untuk meningkatkan Hasil Belajar IPA Siswa Kelas IIIB SD Negeri 188 Pekanbaru 
Penerapan model Quantum teaching dapat meningkatkan hasil belajar bahasa Indonesia siswa. Oleh sebab itu, model ini dapat dijadikan salah satu alternatif pelaksanaan pembelajaran pada pembelajaran bahasa indonesia dalam upaya meningkatkan kualitas proses pembelajaran

\section{DAFTAR PUSTAKA}

Anitah, S. 2009. Teknologi pembelajaran. Surakarta: Yuma Pustaka.

Asep, J \& Abdul, H. 2012. Evaluasi pembelajaran. Yogyakarta: Multi Pressindo.

Deporter, B., dkk. 2000. Quantum teaching: mempraktekkan quantum learning di ruang-ruang kelas. Bandung: Kaifa.

Dimyati \& Mudjiono. 2013. Belajar dan pembelajaran. Jakarta: Rineka Cipta.

KTSP. 2007. Kurikulum Tingkat Satuan Pendidikan. Jakarta: Standar Nasional Pendidikan.

Sutrisno. 2005. Revolusi Pendidikan di Indonesia. Yogyakarta: Ar-Ruzz.

Syahrifuddin, dkk. 2011. Penelitian Tindakan Kelas. Pekanbaru: Cendikia Insani

Trianto. 2009. Mendesain model-model pembelajaran interaktif-progresif. Jakarta: Kencana.

Hainul, Z.P. 2015. Buku Kuliah Terintegrasi (BuKTi): Perencanaan Pembelajaran $S D$. Pekanbaru: Zesya Publisher. 